\title{
Internet Protocols for Mananging the Banking Structure Amoung Foreign Banks
}

\author{
W.Porselvi, N. Mathan Kumar, S. Mari
}

\begin{abstract}
As the Internet winds up being dependably major for trade, objectives are persevering through a relentlessly focal improvement in various affiliations' enchanting structures. The accomplishment of Internet managing a record is settled by banks or government strengthen, what's more by clients' assertion of it. Electronic managing a record solicitation has widened extraordinary idea in competent evaluations amidst the previous an essential drawn-out timeframe as banks advance toward executing Internet putting aside some money as a basic piece of their general procedure. The business favored point of view of web putting aside some money is to pass on extra pay, update client advantage, expand progressing, and develop cost hypothesis saves. In bearing the web and growing its potential, there are a couple of stages that affiliations make through that join planned associations. These moving events of changes are reflected in the different estimations that are open when firms experience the alteration of new improvement, including web keeping money. From the structure audit, some key mentioning was seen, particularly to what degree banks should change their web relationship for clients. The clarification behind this paper was to see those zones where the banks could overhaul or change their relationship to develop the party pace of web keeping money. Information were totaled from non-web keeping money clients by systems for an evaluation study. The results of the respondents were bankrupt down utilizing Structured Equation Modeling (SEM) from which the speculations were attempted and closes drawn. The outcomes from the audit indicated that clients recognize that its hard to utilize web managing a record affiliations, which prompts a reduction over the span of activity of web keeping money.
\end{abstract}

Keywords: Internet Banking, E-commerce, SEM, TAM

\section{INTRODUCTION}

Since the mid-1990s, there has been a basic move in dealing with a record transport toward using self-advantage channels, for instance, web keeping cash. In the midst of the past a significant extended period of time, online dealing with a record affirmation has been quick and current around the

globe. Around $74 \%$ of the private keeping cash customers in Finland are standard customers of web dealing with a record benefits

Revised Manuscript Received on December 30, 2019.

W.Porselvi, Assistant Professor, Department Of Science and Humanities,Bharath Institution Of Higher Education And Research,TamilNadu,India Email: porselviwilson@gmail.com

N.Mathan Kumar, Assistant Professor, Department Of Science and HumanitiesBharath Institution Of Higher Education And Research TamilNadu,IndiaEmail ma.aswinkumar18@gmail.com

T. S. Mari, Assistant Professor, Department Of Science and Humanities,Bharath Institution Of Higher Education And Research TamilNadu,India :Email maripalani09@gmail.com
Table l: Summary of Research Findings on Factors Associated with Internet Banking Adoption

\begin{tabular}{|c|c|c|c|c|c|c|c|}
\hline \begin{tabular}{|l|} 
Factors \\
\end{tabular} & $\begin{array}{l}\text { Gearard and } \\
\text { Cunningham } \\
\text { (2003) }\end{array}$ & \begin{tabular}{|l|} 
Liao \\
and \\
Cheun \\
$\mathrm{g}$ \\
$(2002)$
\end{tabular} & \begin{tabular}{|l} 
Mattilaeta \\
1. (2003)
\end{tabular} & \begin{tabular}{|l|} 
Mouthin \\
hro and \\
Smith \\
(2000)
\end{tabular} & $\begin{array}{l}\text { Retchang } \\
\text { kitunnugai } \\
\text { and } \\
\text { Speece } \\
\text { (2003) }\end{array}$ & \begin{tabular}{|l} 
Sathxe \\
(1999)
\end{tabular} & \begin{tabular}{|l|} 
Wang \\
etal. \\
$(2003)$
\end{tabular} \\
\hline \begin{tabular}{|l|} 
Ease of use \\
\end{tabular} & $\begin{array}{l}\text { Complexity PC } \\
\text { proficiency or } \\
\text { System } \\
\text { upgrade. }\end{array}$ & \begin{tabular}{|l|} 
Expects \\
tions of \\
user- \\
friendli \\
nass
\end{tabular} & $\begin{array}{l}\text { Perceived } \\
\text { difficulty } \\
\text { in using } \\
\text { computers }\end{array}$ & \begin{tabular}{|l|} 
Ease of \\
banking
\end{tabular} & & \begin{tabular}{|l|} 
Lack of \\
arrarane \\
ss about \\
IB \\
\end{tabular} & $\begin{array}{l}\text { Perceiv } \\
\text { ed ease } \\
\text { of use }\end{array}$ \\
\hline \begin{tabular}{|l|} 
Transaction \\
security \\
Transaction \\
accuracy \\
Intennet \\
Speed
\end{tabular} & Confidentiality & \begin{tabular}{|l} 
Expstas \\
tions of \\
sacurity \\
Expats \\
tions of \\
accurac \\
$y$ \\
Expatta \\
tions of \\
networ \\
$\mathrm{k}$ spped
\end{tabular} & & & Security & \begin{tabular}{|l|} 
Securit \\
$y$ \\
concen \\
8
\end{tabular} & $\begin{array}{l}\text { Perceiv } \\
\text { ed } \\
\text { cedibili } \\
\text { ty }\end{array}$ \\
\hline Convenience & $\begin{array}{l}\text { Convenience, } \\
\text { accessibility, } \\
\text { compatibility }\end{array}$ & $\begin{array}{l}\text { Expets } \\
\text { tions of } \\
\text { conveni } \\
\text { ence }\end{array}$ & & \begin{tabular}{|l|} 
Conven \\
ience \\
\end{tabular} & & & \\
\hline
\end{tabular}

\section{REVIEW OF IB ADOPTION:}

Promoting composing has thought about IB from various different viewpoints. Publicizing making has broke down IB from different unquestionable perspectives. A few appraisals separate improvement in IB, while others delineate the focal points to be gotten from IB for an association, and different assessments base on the pieces of protection and security. A thick summary of the various factors related to IB gathering is referenced in Table 1. [1]-[4] An endeavor was made to feature the shared characteristics of these evaluations by get-together relative disclosures from various assessments concerning a practically identical section. 
The most commonly perceived parts are convenience, sentiments of exchange security, speed, and settlement. Despite how these variables are essential in the virtual condition, the conviction of this paper is that there are different parts that besides influence the assurance of IB. Such factors will be seen and are recognized to be client driven instead of improvement or advancing driven.[5]-[10]

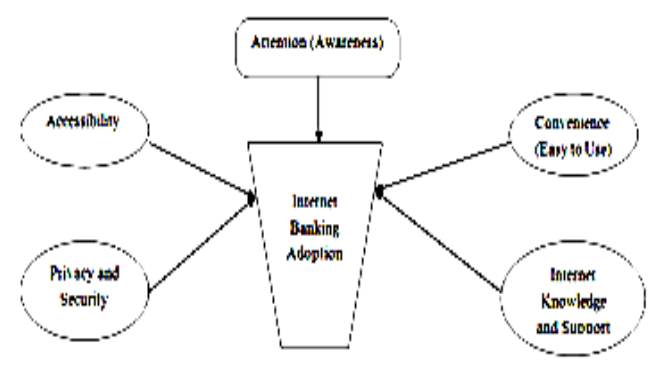

Figure 1: Key factors in consumer adoption of $\mathrm{B}$, a generic theoretical framerwork

\section{ApProAch}

Diverse key solicitation start from the composing survey, explicitly to what degree banks should change their web associations for clients. Especially, which budgetary associations are best disregarded on the web, and by what technique can the web increase the estimation of the bank-client relationship. In keeping an eye out for these huge solicitation, the appraisal had two basic destinations: 1) to get a learning into how relationship-masterminded banks position themselves as to web transport and the associations that they give, a 2) to even more likely welcome the effects on the customer's choice to utilize web banking. [16]-[20]

\section{RESULTS AND CONCLUSIONS:}

The appraisal of the assessment concentrated on the suffering quality and realness of the information and estimation show up, and the way coefficients and passableness of ambush of the fundamental model. The manufactures showed solid internal suffering quality on three measures: Cronbach's Alpha, Composite Reliability and Average Variance Extracted (AVE). The fabricates also demonstrated solid joined and different legitimacy. High marker build loadings demonstrated solid focused validness, while solid distinction was appeared by the cross loadings results. In like way showed is the square base of the AVE whose assurance make respect was higher than the factors of different structures. Likewise, we are enthused about making sense of how well the precursors alone can foresee gathering of IB. Since these components can be evaluated in the midst of the periods of IB, a couple of desires can be made subject to the forerunners to guide organization on the components to consider when elevating IB organizations to non-customers. In order to assess the trustworthiness of these components, the helper model can be envisioned in individualized partitions. [11]-[14]
This examination assessed (5) forerunners to Willingness to Adopt, (3) exogenous and (2) endogenous to measure non-customers of IB and parts that are basic to them. The examination found that two of these free factors - nature of catalysts and data of PCs - essentially foresee wants inside the theoretical model. Additionally, Perceived Ease of Use (how the structure will be free of effort) of the IB system is a basic factor in accepting IB organizations. While autonomously these components can't genuinely anticipate IB gathering, perceiving how these factors are basic to clients would be significant for the officials. These prompt effect models give an average pointer as for what is seen as basic to non-IB customers.[21]-[24]

\section{REFERENCES}

1. Vasanthi, S. \& Rabiyathul Basariya, S. 2019, "Influence of value analysis and cross training in industry", International Journal of Engineering and Advanced Technology, vol. 8, no. 6, pp. 1810-1811.

2. Velvizhi, R., Sri Gowtham, S. \& Jeya Priya, D. 2019, "Examination of early feedbacks for effective product retailing on E-commerce websites", International Journal of Engineering and Advanced Technology, vol. 8, no. 6 Special Issue 2, pp. 703-706.

3. Anuradha, C., Pothumani, S. \& Kavitha, R. 2019, "A novel method towards E-commerce", International Journal of Engineering and Advanced Technology, vol. 8, no. 6 Special Issue 2, pp. 535-538.

4. Thomas, J. \& Rabiyathul Basariya, S. 2019, "A study on the issues of financial ratio analysis", Indian Journal of Public Health Research and Development, vol. 10, no. 3, pp. 1079-1081.

5. Ramachandran, S. \& Rabiyathul Basariya, S. 2019, "Online marketing study on customer satisfaction and relationship", Indian Journal of Public Health Research and Development, vol. 10, no. 3, pp. 1072-1078.

6. Priya, R., Vinothini, G. \& Cor Jesu, C.D. 2019, "The mentor-protégé relationship for professional growth", Journal of Advanced Research in Dynamical and Control Systems, vol. 11, no. 9 Special Issue, pp. 1110-1119.

7. Jannifer Rani, N., Bina Pani, S. \& Nimisha, N.S. 2019, "A study on money back polices available in LIC", Journal of Advanced Research in Dynamical and Control Systems, vol. 11, no. 9 Special Issue, pp. 833-839.

8. Saillaja, V., Jhansi Rani, K. \& Catherine, R. 2019, "Global marketing management planning and organization", Journal of Advanced Research in Dynamical and Control Systems, vol. 11, no. 9 Special Issue, pp. 489-493.

9. Saillaja, V., Jhansi Rani, K. \& Catherine, R. 2019, "The new phase of marketing information system", Journal of Advanced Research in Dynamical and Control Systems, vol. 11, no. 9 Special Issue, pp. 482-488.

10. Thoufiqulla \& Raju, D.V. 2019, "Perception of indian investor towards investment in mutual funds with special reference to mip funds", Journal of Advanced Research in Dynamical and Control Systems, vol. 11, no. 5, pp. 177-183.

11. Jasmine, K.R.M. \& Basariya, S.R. 2018, "A study on the customers benefits on mutual funds", International Journal of Civil Engineering and Technology, vol. 9, no. 4, pp. 45-48.

12. Vasanthi, S. \& Basariya, S.R. 2019, "Pros and cons of on the job training versus off the job training", International Journal of Scientific and Technology Research, vol. 8, no. 10, pp. 671-674.

13. Pavithra, J. \& Ganesan, M. 2016, "A study on awareness and impact of micro-financial schemes", International Journal of Applied Business and Economic Research, vol. 14, no. 8, pp. 5449-5460.

14. Pavithra, J., Dilli Babu, P. \& Ambuli, T.V. 2014, "A study on budgetary control at Maruti Service Masters, Chennai", International Journal of Applied Business and Economic Research, vol. 12, no. 2, pp. 151-161.

15. Gunaraja, T.M. \& Venkatrama Raju, D. 2018, "Determining factors of organisational climate with reference to leadership styles", International Journal of Mechanical Engineering and Technology, vol. 9, no. 9, pp. 1327-1332. 
16. Gunaraja, T.M. \& Venkatrama Raju, D. 2018, "The role of job satisfaction and training of employees in determining organisational climate of a selected industry", International Journal of Civil Engineering and Technology, vol. 9, no. 8, pp. 1266-1269.

17. Aarathy, T.S. \& Raju, D.V. 2018, "Performance appraisal and its effects on employees with respect to it sector in Chennai city", International Journal of Civil Engineering and Technology, vol. 9, no. 6, pp. 1535-1538.

18. Aarathy, T.S. \& Raju, D.V. 2018, "Employee perception towards performance appraisal system in IT sector", International Journal of Mechanical Engineering and Technology, vol. 9, no. 5, pp. 131-135.

19. Porselvi, W., Jublee, D. \& Sivanesan, G. 2018, "A study on factors influencing adoption of technology and innovation in banking industry, tamilnadu, India", International Journal of Mechanical Engineering and Technology, vol. 9, no. 5, pp. 789-800.

20. Akessa, G.M. and Dhufera, A.G., 2015. Factors That Influences Students Academic Performance: A Case of Rift Valley University, Jimma, Ethiopia. Journal of Education and Practice, 6(22), pp.55-63.

21. Miller, G. and Shih, C.C., 1999. A faculty assessment of the academic rigor of on-and off-campus courses in agriculture. Journal of Agricultural Education, 40, pp.57-65.

22. Tsinidou, M., Gerogiannis, V. and Fitsilis, P., 2010. Evaluation of the factors that determine quality in higher education: an empirical study. Quality Assurance in education, 18(3), pp.227-244.

23. Farooq, M.S., Chaudhry, A.H., Shafiq, M. and Berhanu, G., 2011. Factors affecting students' quality of academic performance: a case of secondary school level. Journal of quality and technology management, 7(2), pp.1-14.

24. Fitsilis, P., Gerogiannis, V. and Anthopoulos, L., 2014. Ontologies for software project management: a review. Journal of Software Engineering and Applications, 7(13), p.1096.

25. Adams, J.D. and Jaffe, A.B., 1996. Bounding the effects of R\&D: an investigation using matched establishment-firm data(No. w5544). National bureau of economic research

\section{AUTHORS PROFILE}

W.Porselvi, Assistant Professor, Department Of Science and Humanities,Bharath Institution Of Higher Education And Research, TamilNadu, India

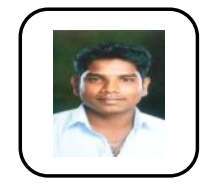

N. Mathan Kumar, Assistant Professor, Department Of Science and Humanities, Bharath Institution Of Higher Education And Research TamilNadu, India

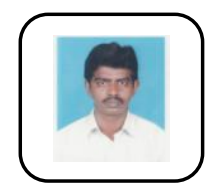

T. S. Mari, Assistant Professor, Department Of Science and Humanities, Bharath Institution Of Higher Education And Research TamilNadu,India 